\title{
Alvin Finkel \\ Social Policy and Practice in Canada: A History.
}

Waterloo: Wilfrid Laurier University Press, 2006. 384 pp.

\section{Christopher Walmsley}

Thompson Rivers University

A single-authored book providing an historical overview of social policy development in Canada is a rare achievement. Not since Dennis Guest's The Emergence of Social Security in Canada (1980, UBC Press) has there been a work on this theme. Sporadically over the past twenty-five years, edited collections such as The "Benevolent" State: the Growth of Welfare in Canada by Moscovitch and Albert (1987, Garamond) and Contesting Canadian Citizenship: Historical Readings by Adamoski, Chunn, and Menzies (Broadview, 2002) have appeared. The history of Canadian social policy, in general though, is a neglected area of academic inquiry. One opens a new book such as this with a measure of anticipation, eager to understand the author's interpretation of major historical themes, controversies, social actors, and achievements. More particularly, how will the author explain Canada's retreat from social policy development over the past thirty years? How is Canada's mix of selective and universal social programs to be understood? How is one to make sense of social policy development in the Canadian federation where, constitutionally, it is a responsibility of provincial and territorial governments and not the federal government? How will the author treat the unique social policy needs of women, indigenous peoples and francophone communities in Canada? This book does not disappoint; instead it provides an engaging dynamic analysis of social movements, political figures, the lives of ordinary citizens and policy achievements in various historical periods.

The book is organized into four parts with two to five chapters comprising each part. The first, titled "Non-State Provision (the Pre-Confederation Period)," provides a three-chapter overview of the earliest foundations of social policy. The chapters provide a contrasting analysis of the approaches taken by First Nations peoples to meet human needs, feudalist church-state provision in New France and the colonial iteration of English poor law in British North America. Differing views and practices 
about care, responsibility, need, and obligation quickly become evident. In the next section of three chapters, "Beyond the Poor Law: 1867 to 1950," there is a discussion of early social policy provision such as workers' compensation, municipal relief programs, workhouses, orphanages, and mothers' pensions. At the same time, the significance of World War I as well as the Depression and World War II are discussed in ways that enable the reader to see the impact of both war and depression on social policy development (pensions for veterans, unemployment insurance) as well as the ways in which women's labour value has changed in different historical periods. The third section, titled "The Welfare State, 1950-1980," discusses, in five separate chapters, social policy and the elderly, medicare, childcare debates, housing and state policy, and anti-poverty struggles. The chapters in this section enable the reader to distinguish clearly the policy achievements in the post-World War II period, the level of public demand and support for universal policy initiatives, the competing interests, and the political compromises. In the final section, titled "Neo-Liberalism," two chapters discuss "The Welfare State since 1980" and "The New Millennium and Social Policy Directions." The first chapter of this section provides an assessment of the victories and defeats of social policy activists in relation to neo-liberal government reforms. The last chapter discusses the future prospects for progressive social policy development in Canada.

There are significant insights to be gleaned from Alvin Finkel's interpretation of the history of social policy and practice in Canada. On the one hand, enduring themes to policy discussions are evident, such as the distinction between the deserving and undeserving poor in Canada. These find expression in today's policy debates, but their origins can be clearly traced to the colonial era of New France and British North America. The theme resurfaces continually over the next three hundred years in debates about social provision. One can also see how decades of social struggle, political controversy and sporadic program initiatives have not led to an adequate basic income, public childcare, or affordable housing for Canadians. These remain unfulfilled dreams of Canadian social policy. At the same time, one can clearly see the self-interest of Canada's economic and social elites in early forms of collective social policy provision such as community hospitals for the sick or compensation for workers injured or deceased as a result of an industrial accident. Women's inequality in Canada becomes self-evident in the ongoing lack of political action taken to implement social policies that would clearly benefit women and children.

Finkel provides a clear analytic lens with which to discuss social policy in Canada. In the introduction he describes himself as a socialist influenced by feminism, and argues that the capitalist system and patriarchy remain constants of post-contact Canadian history. Throughout the book, this analysis is evident in his discussion of the influence of business owners on communities and governments, as well as the role the labour movement and women's organizations have played in their advocacy of policy reform. At several points, he provides an excellent discussion of the role of social workers and social work organizations, such as the Canadian Association of Social Workers, in policy development. This discussion extends his feminist-influenced thinking to an analysis of the role of one of Canada's female-dominated 
professions. Although not discussed directly in the introduction, he implicitly considers the stratification of Canadian society by ethnicity/race and periodically mentions the differential treatment of the Québecois, the Irish and First Peoples. In the opening chapter, he provides an informative discussion of First Peoples' approaches to social care and some of the variations found across tribal affiliations in the precontact period. In most chapters, the concluding section is a brief discussion of First Peoples' colonization under the Indian Act and the consequences of limited social policy provision for them in Canada. Most chapters begin with the story of an individual or family to engage the reader quickly in the social need, controversy, debate, or policy area being addressed in the chapter. A fascinating analysis of key historical events, political leaders, social actors, advocacy groups and social movements then occurs, accompanied by a discussion of the resulting public debates, strategic choices, and political compromises. This analysis is set within a context providing a summary of the specific achievements of policy reform, accompanied by an awareness of the unfulfilled needs, interests, and demands.

Social Policy and Practice in Canada: A History provides an absorbing discussion of all the major social policy areas in Canada except one-education. Some explanation in the introduction about why this important area is not included would be welcome. At the same time, explicit discussion of the faith/culture communitarian basis to social welfare provision in Canada would have been a good addition. Faith and culture have an important history in the provision of health, education and social services in Canada. From Catholic hospitals and Protestant school boards, to Anglican care homes and Jewish family services, to Protestant, Catholic and Aboriginal child welfare services, faith, culture and community are important dimensions that deserve recognition, discussion, and analysis. Overall, these omissions are minor in relation to the dynamic writing, fascinating story-telling, and insightful analysis characterizing this book.

I have used this text with three sections of undergraduate social work students in a required course on Canadian social policy, and have been pleasantly surprised by their enthusiastic response. Social work students, not noted for their love of historical texts, prefer contemporary discussions of interventive methods to history. However, one student described the book in an end-of-course evaluation as "an awesome text." I agree and recommend it wholeheartedly. 